P. WANG, Y. CHENG, C. WU, Y. ZHOU, Z. CHENG, H. LI, R. WANG * W. SU*, L. FANG* (LANZHOU UNIVERSITY AND SHENZHEN INSTITUTE OF ADVANCED TECHNOLOGY, SHENZHEN, P. R. OF CHINA)

Tyrosine-Specific Modification via a Dearomatization-Rearomatization Strategy: Access to Azobenzene Functionalized Peptides

Org. Lett. 2021, 23, 4137-4141, DOI: 10.1021/acs.orglett.1c01013.

\section{Synthesis of Azobenzene-Functionalized Peptides by Modification of Tyrosine-Containing Peptides}

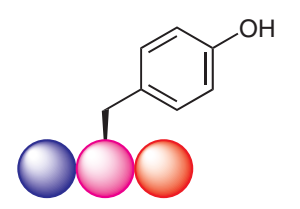

1. $\mathrm{Phl}(\mathrm{OAc})_{2}$ (1.2 equiv) $\mathrm{MeCN}-\mathrm{H}_{2} \mathrm{O}=1: 1$

$0{ }^{\circ} \mathrm{C}$ to r.t., $0.5 \mathrm{~h}$

2. $\mathrm{PhNHNH}_{2}$ (2.0 equiv) $0{ }^{\circ} \mathrm{C}$ to r.t., $3.5 \mathrm{~h}$

\section{Category}

Peptide Chemistry

\section{Key words}

peptide modification

tyrosine

phenylhydrazine

azobenzenes

chemoselectivity

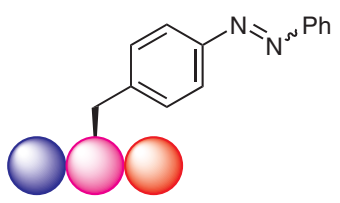<smiles>COC(=O)C(Cc1ccc(N=Nc2ccccc2)cc1)NC(=O)[C@H](C)NC(=O)OCc1ccccc1</smiles>

$50 \%$ yield cis/trans = 29:71<smiles>COC(=O)C(Cc1ccc(N=Nc2ccccc2)cc1)NC(=O)[C@H](CCN)NC(=O)OC(C)(C)C</smiles>

$46 \%$ yield cis/trans $=21: 79$<smiles>COC(=O)C(Cc1ccc(N=Nc2ccccc2)cc1)NC(=O)[C@H](CCSC)NC(C)(C)C</smiles><smiles>COC(=O)C(Cc1ccc(N=Nc2ccccc2)cc1)NC(=O)[C@H](Cc1ccccc1)NC(C)(C)C</smiles>

$48 \%$ yield cis/trans $=20: 80$

$53 \%$ yield cis/trans $=24: 76$<smiles>COC(=O)C(Cc1ccc(N=Nc2ccccc2)cc1)NC(=O)[C@H](CC(=O)O)NC(F)F</smiles>

$56 \%$ yield cis/trans $=10 \cdot 90$
Significance: Azobenzene-functionalized peptides are important because of their distribution in photoresponsive biosystems. The authors report a new strategy for preparing azobenzene-functionalized peptides from tyrosine-containing peptides and phenylhydrazine.
Comment: By using (diacetoxyiodo)benzene, various peptides containing an azobenzene motif were synthesized with good chemoselectivity and site selectivity in moderate yields. 